\title{
Isolation, Purification, and Characterization of Serratiopeptidase Enzyme from Serratia marcescens
}

\author{
Suma.K.C $C^{1}$, Manasa.H ${ }^{1}$, Likhitha. ${ }^{1}$, Nagamani.T.S*1 \\ Department of Biotechnology, Government Science College(Autonomous), Affiliated to Bangalore Central University, \\ Bangalore-560001
}

\begin{abstract}
Serratiopeptidase is a proteolytic enzyme that is derived from a member of Enterobacteriaceae. Serratia marcescens is a gram-negative bacteria identified characteristically, which produces a red pigment called prodigiosin. Serratiopeptidase is a multifunctional proteolytic enzyme that dissolves non-living tissues such as fibrin, blood clots, inflammation in all forms without harming living tissues. In this study, the organism was isolated from the diseased silkworm's pupa by using Luria- Bertani (LB) agar media. The enzyme production can be enhanced by applying different physical and chemical parameters. Serratia marcescens was subjected to production such that in order to obtain the maximum level of cell-free supernatant Serratiopeptidase enzyme with all the optimized conditions. The enzyme was subjected to purification by four methods such as salt precipitation, dialysis, ion-exchange chromatography and gel filtration. When subjected to enzyme kinetics, Serratiopeptidase was active at temperature $35^{\circ} \mathrm{C}$, $\mathrm{pH}-9$ with 8 minutes of the incubation period. The molecular weight of serratiopeptidase by SDS-PAGE was found to be between 50-55kDa.
\end{abstract}

Keywords:- Serratiopeptidase, Serratia marcescens, Silkworm pupa, Luria - Bertani, Ion-exchange chromatography, gel filtration.

\section{INTRODUCTION}

Serratia marcescens is a Gram-negative bacterium, classified under the large family of Enterobacteriaceae[1]. As a human pathogen, $S$. marcescens is involved in nosocomial infections, particularly catheter-associated bacteremia, urinary tract infections and wound infections. $S$. marcescens is a motile organism and can grow in temperature ranging from $30^{\circ}-40^{\circ} \mathrm{C}$ and in $\mathrm{pH}$ levels ranging from 5 to 9 . It is differentiated from other gramnegative bacteria by its ability to perform casein hydrolysis, which allows it to produce extracellular metalloproteinases which are believed to function in a cell to extracellular matrix interactions. Some strains of $S$. marcescens are capable of producing prodigiosin pigment, which ranges in color from dark red to pale pink, counting on the age of the colonies.

Serratiopeptidase, also known as Serrapeptase or Serratia peptidase, is a proteolytic enzyme isolated from the non-pathogenic Enterobacteriaceae Serratia marcescens[2]. This enzyme is naturally present in the silkworm intestine.
The enzyme in its natural form is utilized by the silkworm to dissolve the cocoons and emerge as moths outside.

This enzyme was discovered by German physician Dr. Hans Niper, he discovered it as a "miracle enzyme" for its ability to treat arterial blockage in patients full of arterial coronary disease[3]. The controlled fermentation of Serratia $s p$. secrets serratiopeptidase enzyme within the highly selective medium. Enzyme purification was achieved by ammonium sulfate fractionation and DEAEcellulose chromatography.

Serrapeptidase is a $50-55 \mathrm{kDa}$, alkaline metalloprotease that works to activate the Hageman factorkallikrein-kinin systems of mammals and directly degrades or inhibits $\operatorname{IgG}$ and $\operatorname{IgA}$ immune factors as well as the regulatory proteins $\alpha$-2-macroglobulin, $\alpha$-2-antiplasmin, and antithrombin III[4]. The recovery process involves various steps of filtration, concentration and steps to form enzymes useful for pharmaceutical applications.

Serratiopeptidase possesses benefits in Circulatory disorders and Systemic yeast Infection, FibromyalgiaArthritis- Chronic Joint Pain, Chronic Pain Inflammation, Autoimmune Diseases, Bladder Infections, Fibrocystic Breast Disease, Chronic Fatigue and Clogged ArteriesFibroids Spider Veins -Viral Infection.

\section{MATERIALS AND METHODS}

Collection of sample: Dead and Diseased pupa of silkworm of Bombyx mori Breed were collected (in an airlocked box with some mulberry leaves) from Kolar and Ramanagara District, Karnataka, India.

The isolated microorganism was identified by gram staining, biochemical test and screening [5]. The screening was done to check for a clear transparent zone around the streak to know that casein is hydrolyzed. The stock culture was maintained in LB agar media and allowed to grow at $37^{\circ} \mathrm{C}$ overnight before being used.

\section{$>$ Production:}

For the production of Serratiopeptidase enzyme LB broth was used which contains Tryptone $(10 \mathrm{~g} / \mathrm{l})$, sodium chloride $(10 \mathrm{~g} / \mathrm{l})$, yeast extract $(0.6 \mathrm{~g} / \mathrm{l}), \mathrm{pH}-9$. The medium was sterilized in an autoclave at $121^{\circ} \mathrm{C}$ for $15 \mathrm{lbs}$ before adding the bacterial inoculum. (500ml flask with $200 \mathrm{ml}$ medium, $4 \%$ of inoculum size kept in an orbital shaker for 48 hours at $35^{\circ} \mathrm{C}$ ). After the incubation time for 48 hours, the LB broth was centrifuged at $6000 \mathrm{rpm}$ for 10 minutes. The 
supernatant was collected in a beaker for the purification process and the pellet was discarded.[6]

\section{$>$ Purification of enzyme}

Salt precipitation (Ammonium sulfate ): The collected supernatant in the beaker was taken for the purification step. From this, $2 \mathrm{ml}$ of supernatant was collected in an Eppendorf tube and labeled as crude. The remaining supernatant was measured and poured in a beaker to this magnetic bead was added. The beaker is kept on a stirrer with an ice pack placed in the bowl. $70 \%$ saturated ammonium sulfate was used for purification. $66 \mathrm{~g}$ of ammonium sulfate was added pinch by pinch in $150 \mathrm{ml}$ of obtained supernatant in ice-cold condition for 3-4hours. Later salt suspension was stored in $4^{0} \mathrm{C}$ overnight.[7],[8]

Dialysis: Dialysis is carried out using the cellulose acetate membrane. The salt suspension was centrifuged at 10000 rpm for 10 minutes to remove small molecules from crude enzyme and pellet was collected using $10 \mathrm{mM}$ Tris HCL(10ml) and poured into dialysis bag and kept in magnetic stirrer for 2-3 hours by changing the distilled water at every interval of time. Dialysis is the process of separation of substance in the solution by means of their unequal diffusion through the semipermeable membrane. The solution was placed in a dialysis tube to remove the low molecular weight proteins[9]

Ion-exchange chromatography: The column was filled by DEAE( Diethyl aminoethyl- anion exchange) cellulose gel. It was left to settle down and 7 different illusions using Tris-HCL, $\mathrm{NaCl}$ and autoclaved water were prepared. Dialysis sample was added to the upper layer of the sample and elution buffer was added one by one and collected in their respective tubes.[10]

Gel filtration: The column was filled with Sephadex G-75 gel and allowed to settle down. Selected elution buffer and phosphate buffer was added to the column and collected in 25 different Eppendorf tubes. (i.e., $1 \mathrm{ml}$ each in 25 Eppendorf tubes).

Protease enzyme assay standard: To determine the enzyme activity, where one unit enzyme activity is defined as the amount of enzyme that releases $1 \mu \mathrm{g}$ of tyrosine per $\mathrm{mL}$ per minute. The amount of protein in enzyme extract was measured before and after purification graph is shown in Fig 1[11],[12]

Estimation of Protein by Lowry's method: The aliquots of BSA from $0.2-1.0 \mathrm{ml}$ of BA working standard in 5 test tube and makeup to $1 \mathrm{ml}$ using distilled water, the test tube with $1 \mathrm{ml}$ distilled water serve as blank, add $5 \mathrm{ml}$ of alkaline copper reagent (Reagent $\mathrm{C}$ ) and incubate for 10 minutes. After incubation add $0.5 \mathrm{ml}$ of $\mathrm{FC}$ reagent and incubate for 30 minutes in dark condition, measure the absorbance at 660nm. The graph is shown in Fig 2[13]

Proteases Enzyme assay:0.1 M Potassium Phosphate buffer (a. $\mathrm{KH}_{2} \mathrm{PO}_{4}$ : $25 \mathrm{ml}$ of this is prepared b. $\mathrm{K}_{2} \mathrm{HPO}_{4}$ : $25 \mathrm{ml}$ of this is prepared. add a to $\mathrm{b}$ dropwise to make $\mathrm{pH}$ -
$7), 0.654 \%$ casein was added to the phosphate buffer, $\mathrm{TCA}(6.1 \mathrm{~N})$ was prepared, $\mathrm{Na}_{2} \mathrm{CO}_{3}(0.5 \mathrm{M})$ was prepared, Folin- Ciocalteau. $5 \mathrm{ml}$ of phosphate buffer without substrate was added to test tube and name as Blank, $5 \mathrm{ml}$ of substrate buffer was added to all other tubes, all the tubes were incubated, 5 minutes at $37^{\circ} \mathrm{C}$ for equilibrium, $0.1 \mathrm{ml}$ of enzyme supernatant was added, tubes were incubated at $37^{\circ} \mathrm{C}$ for 10 minutes, $0.5 \mathrm{ml}$ of $6.1 \mathrm{~N} \mathrm{TCA}$ and $0.5 \mathrm{ml}$ of phosphate buffer was added to blank and incubated for 30 minutes at $37^{\circ} \mathrm{C}$, The samples were filtered and $2 \mathrm{ml}$ of the filtrate was transferred to another set of test tubes, $5 \mathrm{ml}$ of $\mathrm{Na}_{2} \mathrm{CO}_{3}$ was added and $0.5 \mathrm{ml}$ of Folin-Ciocaltaue reagent was added to all the test tubes and was incubated in dark for 30minutes. The absorbance was measured at $660 \mathrm{~nm} .[14]$

\section{$>$ Calculation of enzyme activity}

After the standard graph is obtained, the concentration of tyrosine is calculated in $\mu \mathrm{g} / \mathrm{ml}$, this value is converted to $\mu$ moles/ml using the following formula:

amount of enzyme in $\mu g \times$ Molecular Weight of Tyrosine $\times$ Volume 1000

The activity of the enzyme is calculated by the formula and results are tabulated in table 2:

$\underline{\mu \text { mole of } L \text {-tyrosine liberated } \times \text { Total volume of assay } \times \text { Dilution factor }}$ Volume of enzyme $x$ Volume of assay $x$ incubation time

After finding the concentration of protein in the enzyme sample, the specific activity, fold purification, percentage yield of each purified sample was determined using the following formula and results are tabulated in Table 2

Specific activity $=\frac{\text { Enzyme activity in units } / \mathrm{ml}}{\text { Protein concentration of samplen } \mathrm{mg} / \mathrm{ml}}$

Fold of purification $=\frac{\text { Specific activity of sample }}{\text { Specific activity of crude sample }}$

Percentage yield $=\frac{\text { Enzyme activity of sample }}{\text { Enzyme activity of crude sample }}$

\section{$>$ Characterization}

Characterization is the study of the chemical reactions that are catalyzed by enzymes. Characterization was performed using purified enzymes and carried out with protease assay[15]

\section{- Effect of pH on Enzyme activity}

$10 \mathrm{ml}$ of sodium acetate was prepared and $\mathrm{pH} 5$ and $\mathrm{pH} 6$ were set, $10 \mathrm{ml}$ of phosphate buffer with $\mathrm{pH} 7$ and $\mathrm{pH}$ 8 was prepared and $10 \mathrm{ml}$ of glycine buffer with $\mathrm{pH} 9$ and $\mathrm{pH} 10$ was prepared. After this casein was added to all buffer and $100 \mu$ l enzyme was added. The enzyme assay was carried out to determine the enzymatic activity and the results are shown in Fig 3. 


\section{- Effect of temperature on enzyme activity}

A phosphate buffer was prepared and set at optimum $\mathrm{pH}$ 9. Casein was added to all the test tubes with different temperatures. The temperature for incubation was set at $25^{\circ} \mathrm{C}, 30^{\circ} \mathrm{C}, 35^{\circ} \mathrm{C}, 40^{\circ} \mathrm{C}, 45^{\circ} \mathrm{C}, 50^{\circ} \mathrm{C}, 55^{\circ} \mathrm{C} .100 \mu 1$ enzyme was added and enzyme assay was performed. The results are shown in Fig 4.

\section{- Effect of incubation time on enzyme activity}

Phosphate buffer was prepared and set at optimum $\mathrm{pH}$ 9. Casein was added and pasteurized at $75-80^{\circ} \mathrm{C}$ for 30 minutes. The optimum conditions for incubation time were $4 \mathrm{~min}$, $8 \mathrm{~min}$, $12 \mathrm{~min}, 16 \mathrm{~min}$, 20min, $24 \mathrm{~min}$ and $28 \mathrm{~min}$ respectively. $100 \mu 1$ enzyme was added and enzyme assay was performed. The results are shown in Fig 5.

- $\quad$ Effect of substrate concentration on enzyme activity

The substrate was casein taken with different concentrations i.e., $0.2 \%, 0.4 \%, 0.6 \%, 0.8 \%$ and $1.0 \%$ and added to the phosphate buffer and all the optimum conditions were maintained. $100 \mu \mathrm{l}$ of the enzyme was added and enzyme assay was performed. The results are shown in Fig 6.

\section{Molecular weight determination by SDS-PAGE}

Sodium dodecyl sulfate-polyacrylamide gel electrophoresis was done by preparing electrode buffer, separating gel buffer, stacking gel buffer, stock, freshly prepared ammonium persulphate (APS) and SDS, staining solution, destaining solution and SDS loading dye. First, $15 \%$ separating gel was prepared followed by stacking gel, then sonicated for 15 minutes, $0.050 \mathrm{ml}$ APS, $0.100 \mathrm{ml}$ SDS, $0.010 \mathrm{ml}$ TEMED were added into separating gel, then immediately poured into the space between the base plate and notch plate. Allowed it for solidification. Mixed $0.1 \mathrm{ml}$ of each sample such as BSA, crude, salt, dialysis and ion exchange with $0.1 \mathrm{ml}$ of loading dye. Kept it in a water bath for 10 minutes at $85^{\circ} \mathrm{C} \quad$ Then stacking gel was added after mixing it with TEMED, and the comb was placed. After solidification, the comb was removed and samples were loaded and kept in electrophoretic apparatus of voltage $50 \mathrm{~V}$ for 6 hours. Then the gel was kept in staining solution for 24 hours. After that, it was kept in the destaining solution. Finally, the molecular weight of the samples was determined.[16]

\section{RESULTS AND DISCUSSION}

Collection of sample: The silkworms (Bombyx mori) were collected from Kolar and Ramanagara district, Karnataka. India.

The enzyme was identified to be gram-negative bacteria.

\begin{tabular}{|c|c|}
\hline Colour & Red \\
\hline Shape & Circular \\
\hline Elevation & Flat \\
\hline Opacity & Opaque \\
\hline
\end{tabular}

Table 1:- Colony Characterization

\section{Protease enzyme standard assay}

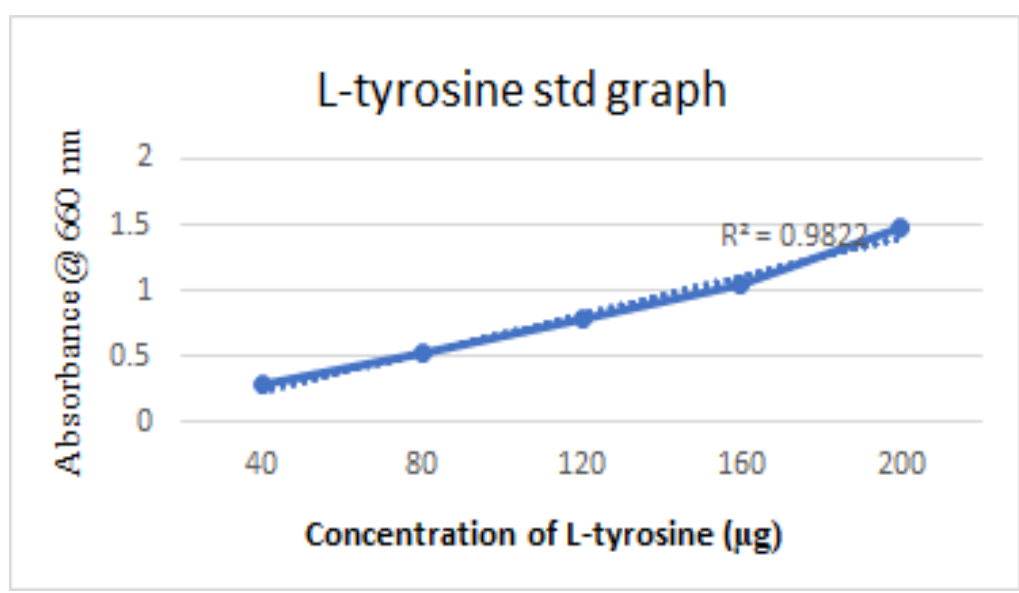

Fig 1:- The graph showing the standard of L-tyrosine 


\section{Protein estimation:}

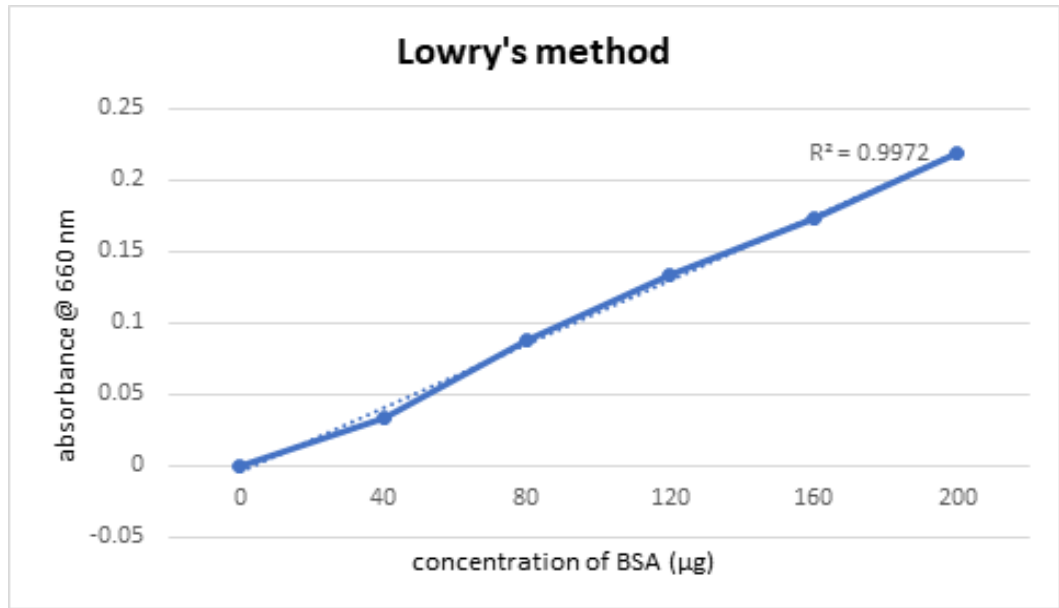

Fig 2:- The graph showing the standard of BSA

\section{Characterization:}

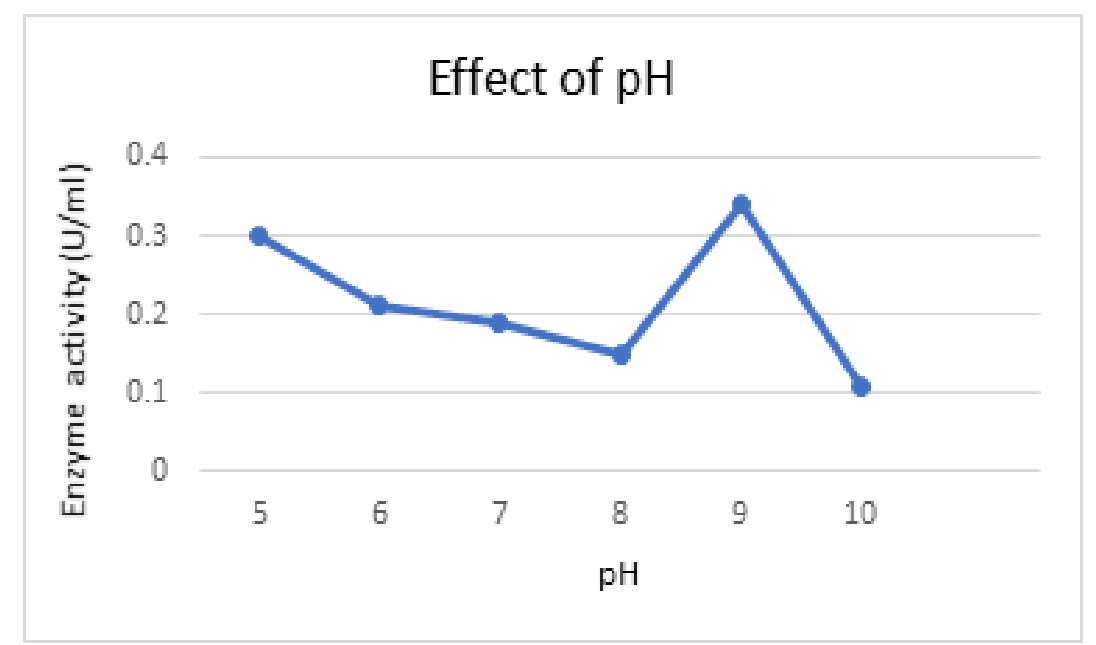

Fig 3:- Enzyme activity at various $\mathrm{pH}$

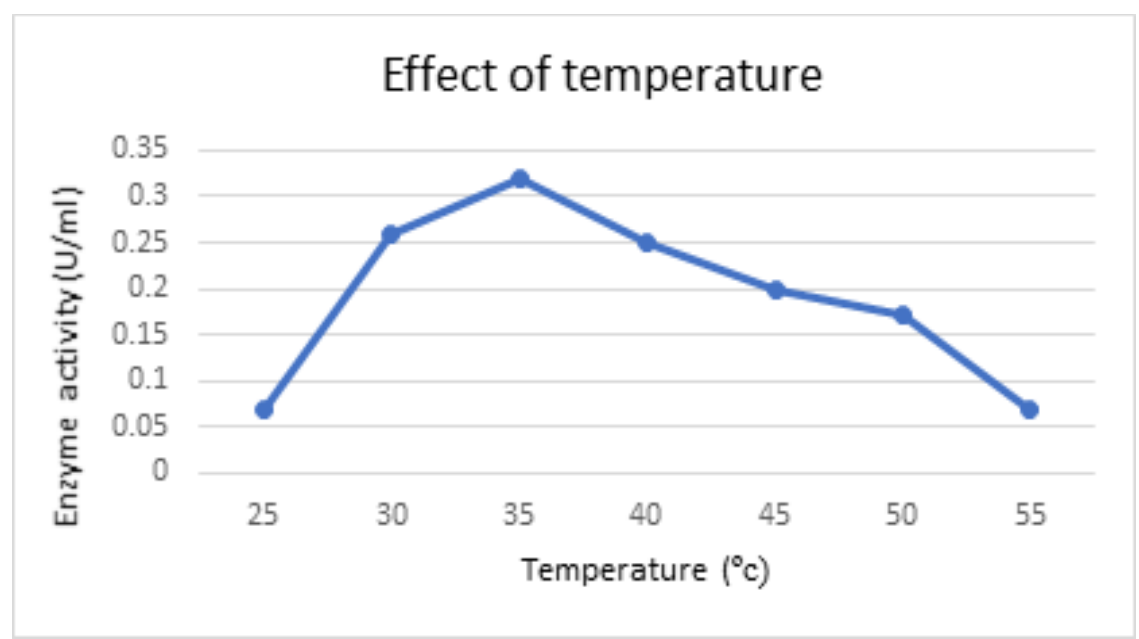

Fig 4:- Enzyme activity at different temperature 


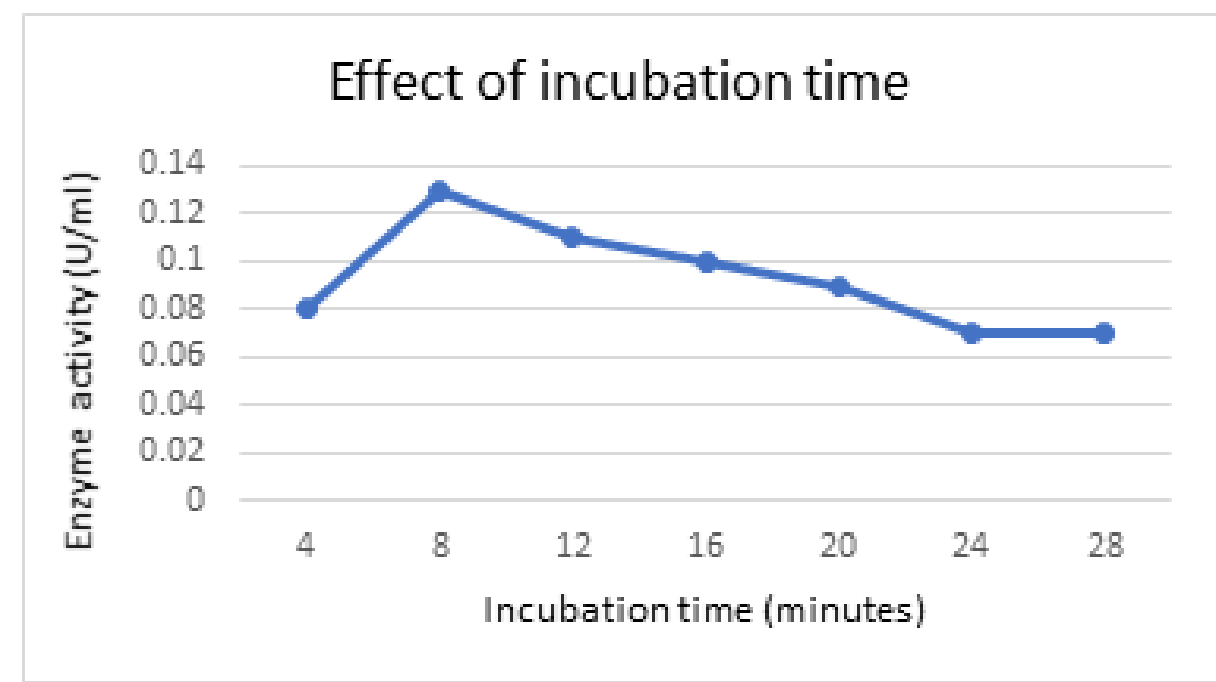

Fig 5:- Enzyme activity at different incubation time

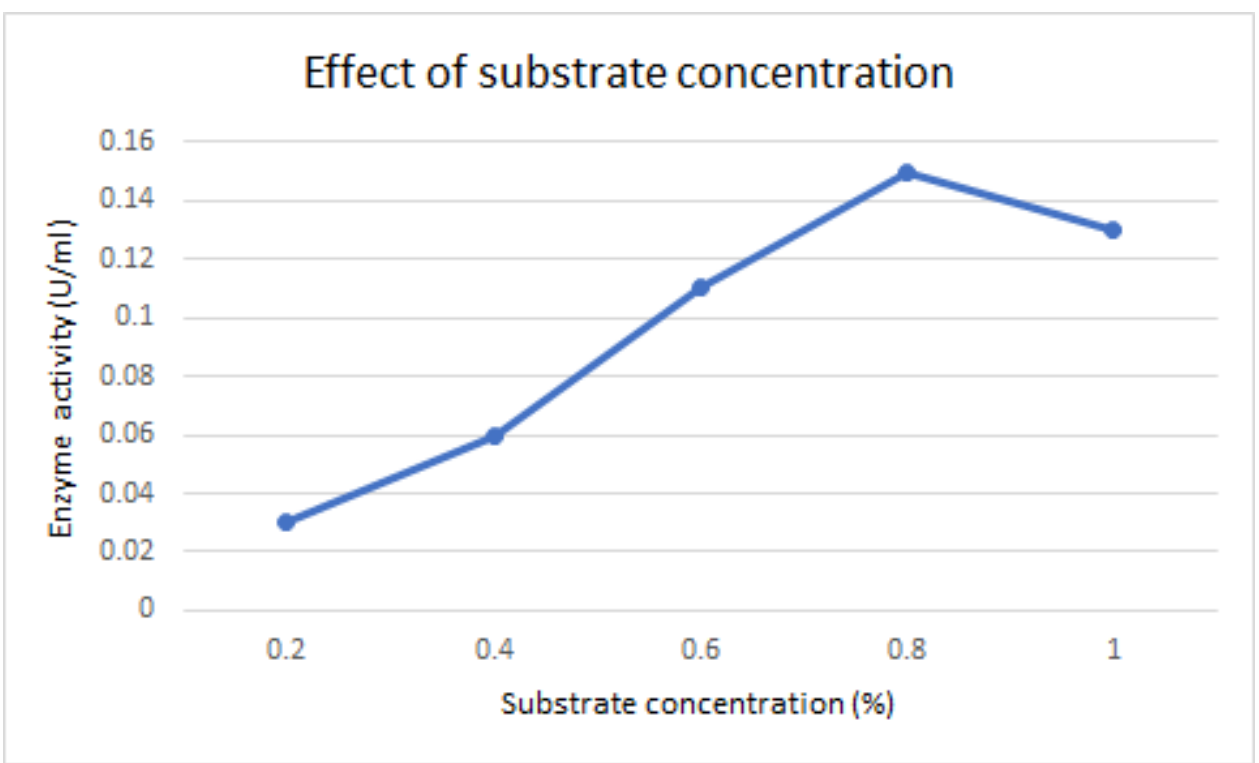

Fig 6:- Enzyme activity at a different substrate concentration

SDS-PAGE

The molecular weight of the Serratiopeptidase enzyme was found to be $55 \mathrm{kDa}$ based on std. BSA marker.

\begin{tabular}{|c|c|c|c|c|c|}
\hline Samples & $\begin{array}{l}\text { Protein conc. } \\
(\mathrm{mg} / \mathrm{ml})\end{array}$ & $\begin{array}{c}\text { Enzyme activity } \\
(\mathrm{U} / \mathrm{ml})\end{array}$ & $\begin{array}{l}\text { Specific activity } \\
(\mathrm{U} / \mathrm{ml})\end{array}$ & Fold & Yield (\%) \\
\hline Crude & 3.46 & 0.089 & 0.025 & 1 & 100 \\
\hline Salt precipitation & 4.28 & 0.082 & 0.019 & 0.21 & 92.1 \\
\hline Dialysis & 3.12 & 0.070 & 0.022 & 0.24 & 78.6 \\
\hline IEC & 1.97 & 0.046 & 0.023 & 0.5 & 51.6 \\
\hline GFC & 1.72 & 0.034 & 0.019 & 0.21 & 38.2 \\
\hline
\end{tabular}

Table 2:- Enzyme purification and activity table 


\section{CONCLUSION}

The microorganism used for the production was the bacterial strain of Serratia marcescens. Serratiopeptidase is being used in many clinical studies against various diseases for its anti-bacterial, analgesic, anti-inflammatory and fibrinolytic effects. Although many bacteria produce serratiopeptidase, Serratia marcescens is the best producer of Serratiopeptidase. An attempt was made towards finding the best growth conditions for the successful cultivation of Serratiopeptidase Enzyme. The enzyme activity was checked at every stage of Purification. Characterization was done to study the optimum conditions for the enzyme activity. Achieving maximum enzyme activity at physiological temperature makes this enzyme extremely valuable in the chemotherapeutic treatment of pain and inflammations.

The apparent molecular weight of Serratiopeptidase by SDS-PAGE was found to be $55 \mathrm{kDa}$. Furthermore, studies have to be made on the application of Serratiopeptidase for treating various diseases.

\section{REFERENCES}

[1]. Caprette.D.R,'Enterobacteriaceae:Serratiamarcescens' '. Overview.http://emidicine.medscape.com/article/2284 95-overview. 2009.

[2]. Noboru Matsumoto, Kyuji kamata, and Ryoichi Okamura."Purification and Characterization of proteases from a clinical isolate of Serratia marcescens" .J. of Bacteriology.1984;157(1):255-232.

[3]. Nieper HA. Basic cardiovascular packet, Richland Centre, Wise: Brewer Science Library. 1999;608:6476513.

[4]. Molla A. Activation of Hageman Factor And Prekallikrein And Generation Of Kinin By Various Microbial Proteinases, J.Biol.Chem.1989;264(18):10589.

[5]. Sneath HAP, Halt GJ."Bergey's Manual of Systematic Bacteriology".Williams and Wilkins Baltimore, MD.1986; Vol 2.

[6]. Olajuyigbe FM, Ajele JO. Production dynamics of extracellular protease from Bacillus species. Afri. J. Biotechnol.2005;4(8): 776-779.

[7]. Gomori, G. Preparation of buffers for use in enzyme active studies. In methods in enzymology.1955; Vol. I. Eds. (Colwick, S. P. and Kaplan, N. O.).

[8]. Dixon M. and Webb, E. G. Enzyme,2 and Edit. Academic Press. Inc. New York.1964

[9]. J. J. Virgin-Ortíz, V. Ibarra-Junquera, J. A. OsunaCastro, P. Escalante-Minakata, N. A. MancillaMargalli, and J. D. J. Ornelas-Paz, "Method to concentrate protein solutions based on dialysisfreezing- centrifugation: Enzyme applications," Anal. Biochem., 2012; vol. 426, no. 1, pp. 4-12, doi: 10.1016/j.ab.2012.03.019.

[10]. R. Dubey, J. Kumar, D. Agrawala, T. Char and P. Pusp. Isolation, Production, Purification, assay and characterization of fibrinolytic enzymes (Nattokinase,
Streptokinase and Urokinase) from bacterial sources. African Journal of Biotechnology. 21 February 2011; Vol.10 (8), pp. 1408-1420.

[11]. McDonald, C. E, and Chen, L. L. "Lowry modification of the Folin reagent for determination of proteinase activity," Anal. Biochem.1965; 10, 175 186.

[12]. Rauf, A., Irfan, M., Nadeem, M., Ahmed I., and Iqbal, H. M. N. "Optimization of growth conditions for acidic protease production from Rhizopus oligosporus through solid-state fermentation of sunflower meal," Intl. J. Agri. Biol. Life Sci.2010; 1, 40-43.

[13]. R. J. R. Oliver H.Lowry, Nira J., Rosebrough, A.Lewis Farr, "Protein measurement with Folin reagent," J.Biol.Chem,1951; no. 193, pp. 265-275.

[14]. Alagarsamy Sumantha, Paul Deepa, Chandran Sandhya, George Szakacs, Carlos Ricardo Soccol, Ashok Pandey; " Rice bran as a substrate for proteolytic enzyme production".Brazilian Archives of Biology and Technology.2006;49(5),843-851.

[15]. El-Safey E. M. and Ammar M. S. Purification and characterization of $\mathrm{NH}-\mathrm{L}$-amylase isolated from Aspergillus flavus var. columnaris. International Conferences Of Enzymes In The Environment, Activity, Ecology And Applications, Praha, Czech Republic,July 14-17,2003; pg 127.

[16]. Ronnle Machielsen, Augustinus, R. Uria, Serve, W.M Kengen, and John Van der Oost. Production and Characterization of a thermostable Alcohol dehydrogenase. That Belongs to the Aldo-keto Reductase SuperFamily. App and Environ Microbiol,2006; 72: P233-238. 